\title{
Um estudo sobre a presença da lírica de Joaquim Cardozo nas histórias de literatura brasileira
}

\section{Elaine Cristina Cintra ${ }^{l}$}

Resumo: Este estudo objetiva analisar como as histórias da literatura brasileira registraram a lírica de Joaquim Cardozo, buscando elucidar quais os processos pelos quais isto ocorreu e como tais procedimentos contribuíram para sedimentar a relevância dessa obra nesse âmbito. Para tanto, foram analisadas sua figuração nos seguintes livros: A literatura no Brasil, de Afrânio Coutinho (1958), História da literatura brasileira, de Massaud Moisés (1989), História da literatura brasileira, de Luciana Stegagno-Picchio (1997), e História da literatura brasileira, de Carlos Nejar (2007). A análise apresenta uma discussão sobre as fontes principais que foram utilizadas no cotejo do assunto por essas histórias, quais os poemas que foram reiterados, e quais perspectivas analíticas foram enunciadas.

Palavras-chave: Poesia brasileira do século XX, História de literatura brasileira, Joaquim Cardozo.

O lugar que a poesia de Joaquim Cardozo ocupa nos estudos literários brasileiros é até os dias de hoje bastante impreciso e nebuloso, uma vez que a crítica que se dedicou ao autor apresentou posições flutuantes, ora o elegendo como uma das maiores expressões poéticas nacionais do século $\mathrm{XX}$, ora o alocando de maneira bastante tênue em grupos regionais, ou até mesmo o ignorando, seja por desconhecimento de sua obra ou pela pregnância de leituras apressadas. Entre uma e outra, a poesia lírica desse autor permaneceu em uma zona de indecisão, que embarga sua produção literária de receber um conhecimento e reconhecimento mais expressivos, cujas razões merecem ser melhor discutidas.

É certo que esse poeta impressionou vivamente três dos maiores representantes da poesia brasileira do século XX, que foram, de certa forma, responsáveis por sua visibilidade no cenário literário da época: Manuel Bandeira, que o incluiu em sua Antologia dos poetas brasileiros bissextos contemporâneos, em 1946, retirando-o, porém, no segundo volume dessa obra, por lhe reconhecer uma produção profícua que o descaracterizaria como bissexto; João Cabral de Melo Neto que atribuía a Joaquim Cardozo a inspiração de sua poesia pernambucana (CABRAL, 1997), tendo incluído seu nome em sua Pequena antologia

1 Professora associada do Departamento de Letras do Centro de Ciências Aplicadas e Letras e do Programa de pós-graduação em Letras, do Centro de Ciências Humanas, Letras e Artes da Universidade Federal da Paraíba. Doutora em Teoria Literária. Email: elcintra@gmail.com 
pernambucana, de 1948; e Carlos Drummond de Andrade, que foi o responsável pelo prefácio do primeiro livro de Joaquim Cardozo, em 1947.

Assim, mesmo apresentado e apreciado por poetas de ressonância inegável na literatura brasileira do século XX, observa-se uma forte oscilação no que se refere à posição ocupada pela poesia de Joaquim Cardozo na cena literária brasileira. A resposta a esta questão, como se sabe, demanda uma reflexão que acione as discussões sobre os modos como se institucionalizam os cânones, e as respectivas perspectivas históricas, ideológicas e estéticas que sinalizam tais valorações.

Como se sabe, a historiografia literária constituiu-se em uma das abordagens mais preponderantes de formação e legitimação do cânone literário nacional. Pode-se dizer também que nos estudos da literatura brasileira, ela se estabeleceu como um instrumental imprescindível nas várias instâncias de leitura e apreciação das Letras, inclusive nas esferas educativas, haja visto que mesmo atualmente, apesar do forte movimento de reposicionamento dos estudos dessa área, dificilmente sua perspectiva é descartada nos vários níveis de ensino.

A discussão aqui desenvolvida propõe mais especificamente examinar como as histórias de literatura brasileira registraram e ajuizaram a poesia lírica de Joaquim Cardozo, na tentativa de investigar algumas hipóteses sobre as formas com que esse autor foi incluído, excluído ou simplesmente relativizado nos cânones literários do século XX, e quais as possíveis razões e ressonâncias que decorreram de tais ocorrências.

Para tanto, serão analisadas sua figuração em algumas histórias da literatura brasileira que percorreram o momento da produção literária do autor. Para tanto, alguns critérios de seleção do corpus foram necessários para este estudo específico. A princípio, fixou-se como primeiro recorte analisar somente as histórias da literatura brasileira publicadas após 1947, ano de publicação de Poemas, primeiro livro de Joaquim Cardozo. Da mesma forma, buscouse obras que contivessem estudos mais estendidos e amplos sobre o autor. O estudo foi direcionado, assim, para quatro tomos específicos: A literatura no Brasil, dirigida por Afrânio Coutinho (1959); História da literatura brasileira, de Massaud Moisés (1989); História da literatura brasileira, de Luciana Stegagno-Picchio (1997); e, por fim, a História da literatura brasileira, de Carlos Nejar (2007).

O levantamento das informações conduziu o tratamento da matéria a um critério cronológico, uma vez que este permite ao leitor entender como o nome de Cardozo foi pautado no panorama das letras brasileiras do século XX nas diferentes décadas, quais as

Gláuks: Revista de Letras e Artes - jul./ dez. 2019 - Vol 19, No 2, ISSN 2318-7131 
visões que foram reiteradas, quais foram revisadas, e quais inovaram as discussões já consolidadas.

De maneira geral, as questões que guiam as considerações tecidas aqui se referem à análise das perspectivas com que a lírica de Joaquim Cardozo se encontra inscrita nas histórias de literatura brasileira acima citadas e quais as fontes e posicionamentos que sustentaram tais escolhas. Para isso, torna-se necessário investigar como a poesia deste autor chegou e continua chegando a seu leitor especializado, o que indiretamente sinaliza para entender os processos de validação de seu nome na bibliografia literária nacional.

\section{Coutinho e o olhar da nova crítica (1958)}

A primeira leitura mais consistente e ampla da poesia de Joaquim Cardozo nas histórias das letras nacionais ocorre em A literatura no Brasil, obra dirigida por Afrânio Coutinho, publicada entre 1952 e 1958; mais especificamente no volume V, o qual, dedicado ao modernismo, surgirá nesta última data, perfazendo assim uma distância de mais de 10 anos da publicação de Poemas (1947), primeiro livro do poeta pernambucano. ${ }^{2}$

Como é de conhecimento, essa obra foi concebida sob a forte influência da Nova Crítica, método engendrado por Afrânio Coutinho após seu contato com o New criticism anglo-saxão na década de 1940, nos Estados Unidos. Em seu projeto, Coutinho propôs uma configuração que se afastava dos modelos até então dispostos na tradição nacional, ao implementar a periodização estilística, que se voltava de maneira privilegiada para as dimensões textuais do objeto, sem, todavia, pressupor o apagamento da problematização do contexto histórico. Além disso, Coutinho optou pelo critério coletivo de construção da história literária, que atribuía o olhar de um especialista a cada assunto.

$\mathrm{Na}$ tentativa de renovar os estudos literários no país, A literatura no Brasil de Coutinho tinha a ambição de atualizar o cânone ao incluir novos autores, ampliando, assim, as referências centralizadas em determinadas regiões e autores. Esta abordagem mais dilatada possibilitou a inserção de Joaquim Cardozo, que será discutido no capítulo 49, "O modernismo na poesia", no item "E - Grupo do Nordeste", juntamente com Ascenso Ferreira, Jorge Fernandes, Jorge de Lima, e Gilberto Freyre. O capítulo será de responsabilidade do

2 Neste trabalho, optamos por usar a $3^{\text {a }}$. edição, de 1986, uma vez que ela é versão atualizada e revista das outras. 
tradutor, ensaísta e poeta Péricles Eugênio da Silva Ramos, cuja produção lírica é contemporânea à de Cardozo.

$\mathrm{Na}$ introdução crítica do capítulo, o modernismo é apresentado como o movimento que decorre da Semana de Arte Moderna até a metade do século XX. O capítulo se dispõe a analisar a poesia brasileira moderna pela já consolidada divisão em três gerações, sendo a terceira, a qual em termos cronológicos supostamente Cardozo seria inserido, a partir de 1945, chamada por Ramos de "fase esteticista", pois marcada pela disciplina e pela pesquisa.

Mais do que o critério cronológico, é a partir do vínculo com sua região que a poesia de Cardozo é discutida no capítulo. Ora, na introdução deste, a visão sobre a literatura do século XX no Nordeste apresentada por Ramos repercutirá fortemente em alguns estudos historiográficos posteriores, como Martins (1965) e Bosi (1970), que viram as expressões literárias da região como reduto de uma tradição de viés conservador, em oposição ao vanguardismo do modernismo no sudeste, posicionamento este que ironicamente a descrição da lírica de Cardozo no capítulo acaba por contestar.

A Joaquim Cardozo ${ }^{3}$, Ramos dedica duas páginas e meia, número considerável se compararmos com as três páginas e meia dedicadas a João Cabral, poeta que já havia tido um grande impacto no cenário literário nacional nessa época ${ }^{4}$, no entanto, bem menos ressoante se o cotejarmos com as nove páginas dedicadas a Jorge de Lima, autor que, em todas as obras aqui consultadas, se situa como a grande expressão da lírica moderna no Nordeste.

Outra questão de ordem editorial que pode ser importante para analisar o espaço concedido a Cardozo nessa história da literatura refere-se à ausência de uma nota biográfica no rodapé, procedimento padrão do capítulo, que se fazia seguir da bibliografia publicada do autor e de sugestões de textos críticos a serem consultados. Além de Cardozo, Ramos omitirá a nota biográfica e bibliográfica de rodapé dos seguintes poetas: Francisco Karam (do grupo Festa), e de poetas enumerados sob a alínea “outros poetas", como Ascânio Lopes, Rosário Fusco, Guilhermino César, Enrique de Resende, Augusto Meyer, Ascenso Ferreira, Carlos Chiachio, José Luís de Carvalho Filho, Américo Facó, Dante Milano, Edgard Braga e Mário Quintana, que receberam uma atenção mais rápida do historiador. Em uma situação particular, Murilo Araújo e Henriqueta Lisboa recebem uma nota de rodapé somente com informações sobre suas publicações, sem a nota biográfica e a sugestão de leitura crítica sobre suas obras. É preciso notar o quanto tais ponderações apontam para uma hierarquização do registro da

3 Curiosidade: mesmo a edição de 1986, grafa o nome do autor em "s": Cardoso, sendo que, na verdade, o autor começou a assinar seu sobrenome com " $z$ " a partir de 1924.

4 Em 1958, João Cabral de Melo Neto já havia publicado ao menos 4 obras de grande importância para a poesia brasileira moderna: Pedra do sono (1942), O engenheiro (1945), O cão sem plumas (1950) e O rio (1954).

Gláuks: Revista de Letras e Artes - jul./ dez. 2019 - Vol 19, $N^{o}$ 2, ISSN 2318-7131 
poesia moderna, seja por uma questão quantitativa, uma vez que alguns autores, Cardozo incluso, haviam até a data publicado um número pouco expressivo de livros, seja pelo desconhecimento de dados de autores que fugiam ao cânone, e que estavam sendo apontados pela primeira vez em uma história da literatura brasileira.

Vale lembrar ainda que a parte do capítulo que se dedica a Cardozo se volta de maneira majoritária para uma leitura textual minuciosa, confirmando sua inclinação para a Nova crítica de Coutinho. Dentre as estudadas, esta é a história da literatura brasileira que enumera um número maior de poemas do autor, ora remetendo a eles por seu título, ora citando literalmente trechos. De fato, são 19 poemas mencionados no capítulo: "Velhas ruas", "As alvarengas", "Tarde no Recife", "Recife morto", "Olinda", "Chuva de caju”, "Imagens do Nordeste", "Poema do homem dormindo", "Autômatos", "Mal-assombrado", "Poema em vários sentidos", "Os anjos da paz", "O soldado", "Afasta de mim o teu corpo", "Menina”, "Canção", "Prelúdio e elegia de uma despedida", "A aparição da rosa", "Arquitetura nascente e permanente". Observa-se que os poemas escolhidos perpassam as várias propostas poéticas do autor durante sua obra, possibilitando um olhar bastante amplo de seus movimentos líricos.

Ramos elabora um percurso de tais movimentos. O início de sua discussão se dá com reiterada citação de Drummond, "modernista mais ausente do que participante" (ANDRADE, 1947, p. 8), colocando em suspenso o estilo moderno nos poemas de Cardozo, destacando especialmente as referências regionalistas em poemas como "Velhas ruas", "As alvarengas", "Tarde no Recife", "Recife morto", "Olinda", "Chuva de caju" e "Imagens do Nordeste". Como se vê, essa apresentação inicial do leitor traz o forte impacto do prefácio do autor de "No meio do caminho" ao demonstrar, como dito no início deste artigo, como a legitimação dos poetas mais renomados do modernismo brasileiro influíam, nesse momento, na concepção da leitura da poesia cardoziana pelos historiadores de literatura.

No entanto, Ramos não se restringe somente a essa clave, conduzindo a questão para outro patamar quando informa que posteriormente à sua estreia Cardozo amplia a temática de sua poética, temática essa que o crítico não chega a mencionar ou esclarecer, mas que pode ser inferida a partir dos dois poemas que ele cita em trechos, "Poema do homem dormindo" e "Mal-assombrado", os quais permitem perceber uma dimensão mais existencial da lírica do autor. Acresce a isto que o capítulo de Ramos também assinala outras perspectivas da poesia cardoziana como a "social" ou "social-utópica" (RAMOS, 1986, p. 156), quando comenta os poemas "Autômatos", "Os anjos da paz" e "O soldado"; e a poesia amorosa-erótica de Cardozo, ao citar "Afasta de mim esse teu corpo", "Menina" e um trecho de "Canção".

Gláuks: Revista de Letras e Artes - jul./ dez. 2019 - Vol 19, No 2, ISSN 2318-7131 
Ao final da parte dedicada a Cardozo, Ramos destaca com atenção especial "Prelúdio e elegia de uma despedida", pela sua composição em vozes, citando nota de seu autor a respeito. É bastante significativo que este poema, depois adicionado a Trivium, tenha sido o único citado em todas as histórias de literatura que aqui foram analisadas, apontando para seu impacto nos leitores desde seu lançamento. ${ }^{5}$

Finalizando a parte relativa a Joaquim Cardozo, Ramos comenta Signo estrelado (1960), apontando para o fato de que neste livro o poeta acrescenta ao lirismo de Poemas o exercício de rimas, citando "A aparição da rosa" e "Arquitetura nascente e permanente", o que direciona para o aspecto racional e artesanal do verso neste poeta, observação também registrada no citado prefácio de Drummond.

Dessa forma, na leitura atenta dos poemas, o autor do capítulo emoldura um panorama inicial bastante significativo da lírica cardoziana, a qual ali estreava nas histórias de literatura brasileira, apontando já para sua permanente inventividade, dado imprescindível para que esse poeta não fosse classificado em parâmetros delimitados, ou modernistas propriamente dito, como o prefácio de Drummond questionara, ou na vinculação estrita a programas regionalistas, o que a crítica literária posterior era detalhou com mais afinco. ${ }^{6}$

\section{Massaud Moisés e a problematização do período literário (1989)}

Publicada em cinco volumes entre 1983 a 1989, a História da literatura brasileira de Massaud Moisés se dedica ao modernismo brasileiro no último deles, no qual Joaquim Cardozo aparecerá no item IV chamado "Tendências contemporâneas", que se dedica à geração de 45 e às expressões subsequentes. Mais especificamente, Cardozo será discutido no item "Retardatários", que, segundo o autor, refere-se aos poetas do modernismo que, apesar de estarem vinculados pela data de nascimento à geração de 22 ou de 30 , tiveram sua estreia literária tardia, "não sem dar margens a mal-entendidos". (MOISÉS, 1989, p. 421). Nesta situação se encontrariam juntamente a Joaquim Cardozo, Dante Milano e Sosígenes Costa.

Em sua apresentação do poeta, Moisés expõe rapidamente uma bibliografia de Cardozo, incluindo aí quatro obras de teatro do autor: O coronel de Macambira (1963), De

5 O poema foi publicado em folheto-livro em 1952, em uma composição composta a mão pelas edições Hipocampo, em cento e dezesseis exemplares em papel ingres, que foram autenticados pelo autor, com ilustração de José Pedrosa.

6 Sobre as complexidades do aspecto regional em Cardozo, recomenda-se lembrar especialmente os trabalhos críticos de Houaiss (1976) e D’Andrea (1998). 
uma noite de festa (1971), Os anos e demônios de Deus (1973) e Antônio conselheiro (1975). Da obra lírica cardoziana até então publicada, Moisés cita Poemas (1947), Prelúdio e elegia de uma despedida (1952) e Signo estrelado (1960). Entretanto não são mencionados três livros do poeta que já estavam em circulação em 1989: Trivium (1960)7 ${ }^{7}$ e Mundos paralelos (1970), ambos reunidos em Poesias completas ${ }^{8}$, e $O$ interior da matéria (1975) ${ }^{9}$, obra norteada pela proposta de uma acurada artesania poética, além de se sobressair pela proximidade que a lírica deste autor apresentava com as artes plásticas.

De maneira geral, o registro da poesia de Cardozo em Moisés é norteado pela ideia de multiplicidade das perspectivas e procedimentos estéticos como marca essencial do autor, que historiador irá manifestar em alguns momentos com ressalva: "Falta-lhe um eixo condutor, uma ideia recorrente, uma solução expressiva preferida. Tudo podia inspirá-lo, todas as modalidades formais the eram familiares e delas fazia uso sempre que o assunto o exigisse." (MOISÉS, 1989, p. 421).

No entanto, é justamente a visão de uma pluralidade nesta poesia que pode ser tida como a melhor contribuição que a obra de Moisés deu à leitura da lírica cardoziana, afastando-se de algumas designações estritamente regionalistas que o poeta havia recebido anteriormente. Entre outras questões levantadas, atribui-se a essa expressão de Cardozo uma condição de independência estética única, que seria o fulcro de uma poesia singular, como no seguinte trecho: "De temática e forma múltipla ou profusa, a poesia de Joaquim Cardozo acompanha menos os modismos que as pulsações anímicas de que se nutre.” (MOISÉS, 1989, p. 421).

Sem citar o prefácio de Drummond, retomando-lhe, no entanto, a ideia de um modernista singular, Moisés postula que Cardozo não teria compromissos senão com sua própria interioridade, e, portanto, apresentaria um modernismo bastante peculiar, que ele chamará de "modernismo intimista", à moda dos fins do século XIX, o que, segundo o autor, o irmanaria com a "loucura" poética de Sousândrade ou Qorpo Santo.

Moisés, de fato, considera Cardozo "simbolista de formação" (MOISÉS, 1989, p. 421), e, para demonstrar tal tese, cita uma das últimas quadras do poema "Prelúdio e elegia de uma despedida", em que o ritmo está fortemente marcado pelas aliterações, rimas internas e

7 Trivium reuniu três poemas de Cardozo: "Prelúdio e elegia de uma despedida", como dito, já publicado em 1952, e os inéditos "Visão do último trem subindo ao céu" e "Canto da serra dos órgãos".

8 A primeira reunião de poemas de Cardozo se deu em Poesias completas, livro publicado em 1971 pela editora Civilização Brasileira, em convênio com o Instituto Nacional do Livro-MEC. A segunda edição da obra se deu em 1979.

9 O interior da matéria foi publicado em 1975 pela editora Fontana, no Rio de Janeiro, em edição limitada, com ilustrações de Roberto Burle Marx, todas as páginas assinadas pelos autores. Cardozo manteria uma intensa relação com outros artistas plásticos, como a obra Chuva de caju, de 1983, em que o poema do autor recebe a ilustração de 12 xilogravuras de Aldemir Martins; ou mesmo seus vários estudos sobre a poesia de Carlos Scliar. 
um tom fluido e vago. Para esse historiador-crítico, o ritmo na lírica cardoziana seria “[...] sempre uma sugestão de estranha e singular beleza [...]”. (MOISÉS, 1989, p. 423).

Nesta linha de argumentação que aproxima Cardozo ao estilo do fim do século XIX, Moisés destaca ainda os elementos religiosos da poesia cardoziana como um fator decisivo para o clima poético do autor. Os aspectos modernos propriamente ditos viriam na desestruturação dos elementos racionais e emocionais do poema, e das configurações da linguagem: "Agita-o uma inquietação que, desestruturando a "lógica" do pensamento e da emoção, se comunica por meio de fragmentos, jactos, fraturas, grafismos, vocábulos em língua estrangeira, números, onde o engenheiro se revela, num plano vizinho do delírio [...].” (MOISÉS, 1989, p. 422). Moisés, então, cita um trecho de "A nuvem Carolina", poema tido por Drummond como uma de suas "companhias silenciosas de vida". (DRUMMOND apud CARDOZO, 2010, p.33). ${ }^{10}$

Por outro lado, Moisés não deixa de anotar o rigor na construção poética desse autor, que apresentaria uma "consciência de artesão do verso" (MOISÉS, 1989, p. 422), aspecto que lhe marcaria a dicção moderna:

[...] sua artesania é a do poeta moderno, sabedor de que a "inspiração" (se dela se tratar) pressupõe ingente trabalho formal. A ponto de anunciar à entrada de "A aparição da rosa e outros sonetos" e de "Arquitetura nascente \& permanente e outros poemas", de Signo estrelado, os tipos de rima que procurou, como autêntico artífice, manusear. (MOISÉS, 1989, p. 422).

Moisés recusa aproximar-se de uma suposta crítica biografista, e evita atribuir essa condição de racionalidade à profissão de engenheiro do poeta: "condição que se reflete, embora escassamente, em sua poesia.” (MOISÉS, 1989, p. 421). Neste viés, conclui que o poeta é "paradoxal", "mas a antinomia é uma das fontes enriquecedoras do lirismo de Joaquim Cardozo.” (MOISÉS, 1989, p. 422).

O registro de Joaquim Cardozo no livro citado de Massaud Moisés pontua um esforço em demonstrar, entre as singularidades poéticas do autor, o envolvimento deste com o período literário em que foi alocado. Assim, ao mesmo tempo em que sustenta a ideia que primeiramente enunciou de uma poesia independente, que possuiria afinal raízes na lírica final

10 A citação completa é: Se me perguntassem: "O que distingue o grande poeta?", eu responderia: "Ser capaz de fazer o poema inesquecível". O poema que adere à nossa vida de sentimento e reflexão, tornando-se coisa nossa pelo uso. Para mim, Joaquim Cardozo, entre os muitos títulos de criador, se destaca por haver escrito o longo e sustentado poema "A nuvem Carolina", que é uma de minhas companhias silenciosas de vida. (DRUMMOND apud CARDOZO, 2010, p.33) 
do século XIX, o historiador busca trazer os aspectos que situariam esta poética, por sua forma tensa e racional, na linhagem de Valéry.

\section{Stegagno-Picchio e o olhar estrangeiro (1997)}

A História da literatura brasileira da filóloga e professora de literaturas neoromânicas Luciana Stegagno-Picchio foi publicada em 1997 pela editora Nova Aguilar. Como o prefácio da edição informa, esta obra consiste em uma versão de La letterattura brasiliana, publicada em 1972, 42. 'volume da coleção "Le letterature del mondo", em Florença-Milão, e foi inicialmente postulada para um público estrangeiro, portanto, a versão brasileira, como informa a autora no "Prefácio à edição brasileira", foi adaptada e atualizada.

$\mathrm{O}$ volume de Stegagno-Picchio se faz singular pois, apesar de toda a familiaridade com a cultura brasileira e a língua portuguesa, tratando-se de uma autora que teve sólida proximidade com escritores e intelectuais do país, além de ser estudiosa e tradutora da literatura brasileira e portuguesa, consiste, afinal, no único exemplar do corpus aqui discutido que apresenta um olhar estrangeiro, assim, presumivelmente marcado por um maior distanciamento.

$\mathrm{Na}$ "Nota editorial", no entanto, os editores atentam para algumas dificuldades, especialmente no que se trata à recolha do material, afirmando que, em razão da falta de distanciamento temporal e da dificuldade de acesso às obras, as últimas décadas teriam sido analisadas "de forma mais subjetiva e impressionista, reflexo da própria incerteza de contornos de toda a visão contemporânea." (STEGAGNO-PICCHIO, 1997, p. 10).

$\mathrm{Na}$ introdução, Stegagno-Picchio traça a linha matriz que conduziu sua História da literatura brasileira: a procura e descrição de um "estilo brasileiro", que faria da sua uma "história literária do "como"”. (idem, ibidem, p. 21). Dessa forma, mais do que uma leitura cronológica, a apreciação da autora atravessa a quase imaginária linha da história com a crítica, além de envergar a perspectiva de uma pesquisadora de formação filologista e que foi, inclusive, colaboradora de Roman Jakobson. Esta ambiguidade é, inclusive, assumida pela estudiosa que afirma ter "ecletismo metodológico" (idem, ibidem, p.22), ficando sua história literária entre a História e a tradição estilística, "embora, talvez, o critério estilístico tenha sempre prevalecido sobre os demais." (idem, ibidem, p. 23).

Gláuks: Revista de Letras e Artes - jul./ dez. 2019 - Vol 19, No 2, ISSN 2318-7131 
Joaquim Cardozo é citado neste livro no capítulo décimo quarto, mais especificamente no item “A grande poesia de consolidação", descrito pela autora da seguinte forma:

Fechada a fase polêmica e destrutiva, eliminando o excesso de Brasil da página literária, exauridos os jogos primitivistas e antropofágicos, a poesia brasileira, sólida nas suas conquistas técnicas, na sua liberdade construtiva, pode começar a sua segunda aventura modernista. Nasce aquela que chamaremos a grande poesia de consolidação. (STEGAGNO-PICCHIO, 1997, p. 544).

Sob este item, a autora introduz Jorge de Lima, Murilo Mendes, Carlos Drummond de Andrade, Cecília Meireles, Augusto Frederico Schmidt e Cassiano Ricardo. Em um subitem chamado "Ainda poetas", Stegagno-Picchio remete brevemente, e por uma perspectiva regional, a poetas de Minas Gerais, Rio Grande do Sul, e aquilo que chama de "grupo no Nordeste", para o qual destina alguns parágrafos, citando Ascenso Ferreira e Joaquim Cardozo, sendo que o último recebe da historiadora um olhar bem mais alongado - 15 linhas, fora uma citação de trecho do poema "Prelúdio, elegia de uma despedida", em detrimento das três linhas do primeiro. De fato, ao tratar de Cardozo, Stegagno-Picchio foge da categorização fácil de "poeta regionalista" já no início de seu estudo da poesia de Cardozo ao afirmar que o lírico apresenta perspectivas mais amplas do que o regionalismo: “[...] que saberá partir do regional (o Recife natal, o Nordeste seco e preciso de Graciliano Ramos e de João Cabral) para chegar ao universal. Apenas 'paisagem, profundamente'”. ${ }^{11}$ (STEGAGNO-PICCHIO, 1997, p. 567).

Mais do que a questão universal, a autora aponta para a introdução na cultura brasileira de "[...] elementos inconsuetos: Morgenstern, por exemplo, e os seus estrepitosos Galgenlieder." ${ }^{2}$ (STEGAGNO-PICCHIO, 1997, p. 568). Este fator, que em muito amplia as referências da poesia cardoziana, aponta para o voraz leitor e conhecedor de outras culturas que marcou Cardozo como um dos intelectuais mais erudito de sua época, como atestam vários testemunhos de seus companheiros. Pode-se dizer, então, que o olhar para a "internacionalização" do autor talvez seja a contribuição de Stegagno-Picchio advinda de seu status de leitora europeia.

A autora também aborda o modernismo em Joaquim Cardozo ao citar a quase obrigatória frase de Drummond em seu prefácio, "modernista mais ausente do que

11 Trata-se aqui da citação literal de um dos versos do poema "Imagens do Nordeste", publicado por Cardozo em Poemas. (CARDOZO, 1947 , p. 98)

12 Trata-se de uma coleção de poemas do alemão Christian Morgenstern, do início do século XX. 
participante" (ANDRADE, 1947, p. 8), e que, como se pode perceber a esta altura desse artigo, determinou uma visão do poeta nas histórias da literatura brasileira.

Stegnano-Picchio atribui a "descoberta" de Cardozo especialmente a três fatores: a publicação de Poemas em 1947, a inclusão de seu nome na antologia de João Cabral, Pequena antologia poética pernambucana, em 1948, e a publicação de seus textos subsequentes: Prelúdio, elegia de uma despedida, na década de 50, Signo estrelado, na década de 60, e Um livro aceso e nove canções sombrias, na década de 80. A questão do impacto do autor é também levantada ao ser apresentada as particularidades da lírica deste poeta:

Por isso, os seus objetos (o relógio, o homem que dorme, as coisas todas cristalizadas pelo tempo na sua dimensão natural) e o seu modo de orquestrar a partitura poética, deixando o leitor livre para organizar a seu gosto as intervenções, atraem os mais jovens poeta de hoje. (STEGAGNO-PICCHIO, 1997, p. 567).

No item "Bibliografia" do capítulo, a historiadora italiana arrola a Poemas, Signo estrelado, a edição de Poesias completas, e Um livro aceso e nove canções sombrias, livro póstumo do autor organizado por Audálio Alves. Como Moisés, ela omite $O$ interior da matéria, o que não é incompreensível, dada a circulação bastante restrita dessa publicação.

Um outro dado refere-se a fato de que, ao contrário do que realiza com quase todos os autores citados em sua História da literatura brasileira, Stegagno-Picchio não enumera nenhuma bibliografia crítica de Cardozo, ou por dificuldade ao acesso de tais realizações, dado sua condição de estrangeira, ou pelo ainda baixo impacto das leituras sobre Cardozo nos estudos de literatura brasileira.

De modo geral, a inserção da poesia de Joaquim Cardozo ocorre no livro de StegagnoPicchio de maneira breve mas incisiva. Em sua proposta de um panorama conciso, ela consegue demonstrar as questões que moveram inicialmente a crítica e estudos historiográficos que registraram a obra do autor, ampliando a perspectiva para outras visadas; além disso, de maneira rápida, apresenta questões do estilo do poeta, discute como se deu sua recepção e registra o impacto da lírica cardoziana nos poetas de hoje; e, por fim, da mesma forma que percorre nessas poucas linhas o trajeto da crítica inicial a mais recente, ela acrescenta um olhar estrangeiro à leitura de Cardozo.

Stegagno-Picchio, então, contribui para uma visada valorativa dessa poesia, ao mesmo tempo em que o coloca sob o viés de uma nova historiografia, que não omite suas 
prerrogativas críticas, prerrogativas essas que se cruzam e se amalgamam, propiciando um olhar mais amplo e atual do objeto.

\section{Carlos Nejar e o olhar exacerbado (2007)}

A História da literatura brasileira de Carlos Nejar foi publicada em 2007, e propõe repensar este tipo de discurso a partir de uma operação de decomposição e recomposição das escritas historiográficas de até então. Trata-se de um compêndio, cujo autor é um poeta premiado e consolidado na mais recente cena literária nacional, que traz a proposição de ser redigida em um estilo íntimo, o qual não se determinaria pela suposta objetividade do historiador. Esta intenção se faz mais clara quando, em sua "Apresentação", Nejar aponta para a mobilidade do processo criativo a que pretendeu desenvolver na escrita dessa história, processo este que não se atém nessa obra a uma ordem temporal, mas que o autor presume se reconstruir incessantemente: “o tempo é reinventável” (NEJAR, 2007, p. 11).

Nejar apresenta suas escolhas como provenientes de uma "perspectiva pessoal da literatura brasileira", mencionada pelo autor até mesmo como autobiográfica, perspectiva essa que, segundo ele, desde a Geração de 1960, a que ele se filia, teria se tornado possível. Sem hesitação, comenta que nomes e critérios alinhados partiram de sua antologia pessoal: "E não escrevo esta História para ferir ou estimular - isso não mudaria em si a literatura. Escrevo-a por acreditar que a visão de um, acrescentada à de outros, há de mudar o modo de a entender." (NEJAR, 2007, p. 13-14). No entanto, o estilo subjetivo a que propôs apresenta alguns limites: o autor se esquiva de falar de sua própria geração confessando não haver uma devida imparcialidade de sua parte para realizar a tarefa.

De maneira geral, o tomo de Nejar pretende apresentar uma tessitura diversa em relação a suas antecessoras, no que se refere ao estilo linguístico com que é redigida. Uma das razões para isso, é que o autor foge de uma cronologia rígida, ao encetar relações entre autores, tanto da mesma época como de outras diversas, apesar de manter uma linha cronológica principal mas não rígida, com alguns "desvios" em alguns momentos, ao trazer relações que se realizam por questões diversas, ora temáticas, ora relacionadas aos procedimentos linguísticos. No entanto, é importante notar que não há uma uniformidade neste processo, e, em alguns capítulos, reconhece-se não somente o estilo das histórias de literatura tradicionais, como seus posicionamentos e informações.

Gláuks: Revista de Letras e Artes - jul./ dez. 2019 - Vol 19, No 2, ISSN 2318-7131 
Apesar dessa conjetura de atualização de estilo do discurso historiográfico, a ideia de reafirmar um cânone ainda está em andamento, o que se confirma na explicação da orelha do livro: "O critério seguido neste trabalho é o de reunir os mais significativos autores de nossa cultura. Reflexo da inventividade de um povo". (NEJAR, 2007, orelha do livro). Por outro lado, ao expor as escolhas realizadas, Nejar aponta a pretensão de ampliar de maneira "ciclópica" o olhar para a literatura brasileira, ao cotejar em um modo mais verticalizado e amplo as várias regiões do país:

Fixo, assim, o critério seguido neste trabalho ciclópico, reunindo autores, a meu ver, os mais significativos, com obras publicadas até a década iniciada com a fundação de Brasília, que se deu em 21 de abril de 1960, vislumbrando "o conjunto de regiões que formam verdadeiramente o Brasil. Somos um conjunto de regiões, antes de sermos uma coleção arbitrária de Estados", escreveu Gilberto Freyre [...]. E a literatura abrange os autores de todas essas regiões no panorama global brasileiro, que é um continente. Cumprindo-se a visão de Ralph Emerson de que cada nova época exige nova confissão, esperando esse mundo pelo seu poeta (no sentido mais amplo, pelos seus criadores); o que se já nasceu, o tempo revelará." (NEJAR, 2007, p. 12).

De fato, a História de Nejar é a que oferece um maior espaço para poetas de regiões distintas, e, voltando-se à região nordeste propriamente dita, são discutidos alguns nomes como César Leal, Alberto da Costa e Silva e Mauro Mota, que não serão encontrados em outras expressões dessa natureza.

Joaquim Cardozo é apresentado em Nejar no capítulo 25, “Outros poetas e alguns do segundo Modernismo", juntamente a Dante Milano, Jorge de Lima, Carlos Drummond de Andrade, Murilo Mendes, Cassiano Ricardo, Ribeiro Couto, Ronald de Carvalho, Menotti del Picchia, Augusto Meyer, Abgar Renault, Guilhermino César, Rosário Fusco, Alphonsus de Guimaraens Filho. De fato, o autor de “As alvarengas” é o primeiro poeta a ser mencionado, sob o item "Joaquim Cardozo, ou a engenharia do inefável".

Nejar apresenta Joaquim Cardozo como um poeta maior, usando adjetivos altissonantes, entusiasmados e afirmando a precedência deste poeta a Drummond e Cabral:

João Cabral foi engenheiro do verso, depois dele; e ao ser lido, descobrimos esta objetividade do inconcreto, as linhas que, de vívidas, jamais envelhecem, irmãs de Oscar Niemeyer. Cabral partiu para o mais prosaico e mais concreto. Joaquim Cardozo é "lição das coisas", antes de Drummond, a mágica divisa. O que soube reavivar o pensamento de Novalis: "A poesia é que cura as feridas do entendimento." E o entendimento cura as feridas da poesia. (NEJAR, 2007, p. 233234).

Gláuks: Revista de Letras e Artes - jul./ dez. 2019 - Vol 19, No 2, ISSN 2318-7131 
Em comparação aos demais textos historiográficos aqui analisados, Nejar apresenta informações mais alargadas do autor e de sua obra. Ao falar de sua biografia, menciona o episódio da queda do pavilhão da Gameleira, em Minas Gerais, pelo qual o poeta foi condenado em primeira instância, e que o abalou de maneira profunda e definitiva. $\mathrm{Na}$ questão crítica, traz referências a leitores pernambucanos, citando César Leal e Maria da Paz Ribeiro Dantas, renomados estudiosos do poeta. Além disso, é o único que menciona diretamente uma das críticas mais impactantes recebidas pela poesia de Cardozo, a leitura que José Guilherme Merquior (1968) realizou de "Canção elegíaca", poema tido por Nejar como uma "elegia antológica".

Em relação à menção de poemas, Nejar apresenta "Prelúdio e elegia de uma despedida", "Imagens do Nordeste", "O relógio", "Soneto sobre os motivos de Chagall", "Maria Bonomi", "Maria Gravura", "Sonetossom", "Soneto da vinda", "Soneto do indigente", "O cego", citando trechos de alguns ao exemplificar algumas das características que levanta: a aproximação do fazer poético com o cálculo matemático, a referência à sua terra natal, a convivência entre os elementos eruditos e populares, a lírica amorosa. No entanto, o historiador elege como objeto de preferência "Visão do último trem subindo ao céu", que considera a obra prima cardoziana, marcada, segundo ele, por uma originalidade "sem confronto em língua portuguesa” (NEJAR, 2007, p. 233): “Apenas a sua criação já seria dádiva de uma aventura que delineia a alta poesia, a da aventura humana." (idem, ibidem, p.233). O tom entusiasmado também se segue na descrição da linguagem do poema: "Essa linguagem tem dentro de si 'a superioridade do exílio' de uma linguagem que se adentra nos mergulhos do indizível." (idem, ibidem, p.233).

Outro aspecto que diferencia a história de Nejar com a de seus predecessores, é a consideração ao teatro de Cardozo, que ocorre em Moisés somente na menção de $O$ coronel de Macambira, De uma noite de festa, Os anjos e demônios de Deus e Antônio Conselheiro. A tais títulos, Nejar acrescenta a Obra teatral de Joaquim Cardozo (2001), publicação que reúne todo o teatro do autor.

Além do item no capítulo 25, Nejar ainda menciona Joaquim Cardozo três vezes: na página 212, ao falar do poeta baiano Sosígenes Costa, ao mencionar uma das questões mais enfatizadas pela crítica cardoziana, o tema da solidão em seus poemas, ou, em uma perspectiva biográfica, a sua solitária figura. $\mathrm{O}$ autor de Poemas também ressurge na página 274, ao ser discutida a poesia de Guilhermino Cesar, que, apesar de pertencer à geração de

Gláuks: Revista de Letras e Artes - jul./ dez. 2019 - Vol 19, $N^{o} 2$, ISSN 2318-7131 
Carlos Drummond, Murilo Mendes, Emílio Moura, juntamente com Abgar Renault, Dante Milano e o próprio Cardozo, receberam um reconhecimento tardio. Por fim, Cardozo se faz presente na página 533, nos comentários das referências principais da lírica de César Leal, poeta que se dedicou sistematicamente aos estudos da literatura de Cardozo, tanto na organização de uma antologia de poemas do mesmo, quanto na atividade crítica e ensaística.

Não há dúvida, como foi verificado acima, que Nejar, além de atualizar as referências do autor, intensifica o lugar de Cardozo na historiografia nacional, ao tratá-lo como um autor de extrema relevância na poesia brasileira do século XX. Peca-lhe a grandiloquência e extrema subjetividade do estilo, que poderá direcionar o leitor a entender o registro com ressalvas.

\section{Considerações finais}

A este ponto, já é possível tecer algumas considerações e hipóteses pautadas na análise acima, posto que esse estudo permitiu sondar, entre outros, as fontes mais consultadas, as discussões, os poemas e temas mais reiterados, e os movimentos de atualização que a produção literária de Joaquim Cardozo recebeu nas histórias da literatura brasileira aqui nomeadas.

É interessante notar que, em relação aos 28 poemas citados, mencionados ou discutidos nas quatro obras, tanto em trechos ou na transcrição integral, 17 são provenientes do primeiro livro de Cardozo, Poemas: "Velhas ruas, "As alvarengas", "Tarde no Recife", "Olinda", "Chuva de caju", "Imagens do Nordeste", "Poema do homem dormindo", "Autômatos", "Mal-assombrado", "Poema em vários sentidos", “Os anjos da paz", "O soldado", “Afasta de mim esse teu corpo", "Menina", "Canção", “O relógio".

De fato, todos esses textos de Poema estão inclusos no capítulo de Ramos, em $A$ literatura no Brasil, de Coutinho. Ora, a preeminência desse livro na história literária de Coutinho é facilmente compreensível, não somente por essa obra historiográfica propor um olhar mais direcionado às composições literárias propriamente ditas, o que justificaria o número de textos poéticos no estudo, mas também pelo fato de essa história da literatura brasileira ter vindo a lume em 1959, momento em que Cardozo havia publicado somente seu primeiro livro de poemas. Acresce a esse dado a menção de Ramos a "Prelúdio e elegia de uma despedida", que fora publicado em 1952, em edição especial e restrita pela Hipocampo e

Gláuks: Revista de Letras e Artes - jul./ dez. 2019 - Vol 19, $N^{o}$ 2, ISSN 2318-7131 
que mesmo com essa condição de circulação já é elencado na seleção do capítulo. Em outra situação se encontra "Arquitetura nascente \& permanente", poema que foi impresso pela primeira vez em outubro de 1959 na revista Módulo, o que, pela data, torna impossível sugerir que tenha sido esta a fonte do historiador, tal como "A aparição da rosa", estampado em Signo estrelado em 1960, o que nos leva a inferir que tais textos foram acrescentados nas edições posteriores em Coutinho.

Por outro lado, apesar de citar "Imagens do Nordeste" e "O relógio", Nejar, ao listar no início do capítulo as obras poéticas de Joaquim Cardozo, não menciona, por razão não esclarecida, justamente o primeiro livro do autor no qual tais poemas se encontram. A explicação possível seria que os poemas acima foram coletados da edição Poesias completas, que o autor menciona, ou nas antologias e publicações em periódicos. ${ }^{13} \mathrm{O}$ possível desconhecimento da edição de Poemas provavelmente explicaria também o fato de ter sido o único dos historiadores aqui estudados que não menciona em nenhum momento o antológico prefácio de Drummond.

Mundos paralelos, que será publicado na edição de Poesias completas em 1971, comparece somente na História da literatura brasileira de Nejar através da menção a cinco poemas: "Maria Bonomi, Maria gravura", "Sonetossom", "Soneto da vinda", "Soneto do indigente", "O cego". De Signo estrelado, Nejar menciona "Canção elegíaca”, "A aparição da rosa", (que também recebeu menção de Péricles/Coutinho e de Moisés) e "Soneto dobre os motivos de Chagall".

Apesar de ser a mais recente das obras que se constituíram o corpus do estudo aqui proposto, Nejar somente lista $O$ interior da matéria e Um livro aceso e nove canções sombrias, sem, no entanto, destacar desses nenhum poema. Moisés e Stegagno-Picchio também não se voltam para os poemas desses livros, mesmo tendo eles sido publicados antes de suas respectivas histórias de literatura. Tal dado permite-nos entender que Signo estrelado e Mundos Paralelos assumiram um lugar de destaque no âmbito das histórias da literatura brasileira mais recentes que tangenciaram a lírica de Cardozo, ainda mais fortemente o primeiro, único tomo do poeta que foi mencionado por todos os quatro autores aqui analisados.

13 Os poemas de Joaquim Cardozo compareceram em várias antologias importantes de poesia brasileira moderna, tendo sido Manuel Bandeira, talvez, o autor que maior atenção deu a este poeta em suas antologias, uma vez que, com exceção de Antologia dos poetas brasileiros: poesia da fase moderna (depois do Modernismo), o menciona em todas as obras desse gênero que organizou. "Imagens do Nordeste", por sua vez, representa um caso de expressiva notoriedade, pois até a ocasião da publicação de Nejar, o poema já havia sido vastamente divulgado, entre outros, e afora as antologias bandeirianas, na Pequena antologia pernambucana (1948), de João Cabral de Melo Neto; no volume VI (O Modernismo) de Panorama da poesia brasileira (1959), de Mário da Silva Brito; na coletânea Sonetos e canções (1960), publicada em Salvador; em Poesias completas (1971 e 1979); no volume V de Poetas do modernismo, de Leodegário A. de Azevedo Filho; em Poemas selecionados (1996), seleção de César Leal que inclusive foi mencionada por Nejar em seu texto. 
O poema cardoziano, no entanto, que receberá o maior reconhecimento será "Prelúdio e elegia de uma despedida", o qual foi colocado em relevo pelos quatro historiadores. O texto de 1952, como dito acima, foi bastante reproduzido, tendo sido transcrito em 1961 na revista Módulo, em número especial sobre Cardozo, e, a partir de 1971, como dito, como parte de Trivium, publicado em Poesias completas, livro esse que se tornou o principal guia de leitura dos poemas do autor por, ao menos, as três décadas seguintes a sua divulgação. Tal obra, aliás, é literalmente citada por Moisés no rodapé como fonte das referências dos poemas que constam no item que o estudioso dedicou a Cardozo.

Sobre Trivium ainda é interessante notar que Nejar focou sua leitura de Cardozo justamente na discussão crítica dessa obra, e chegou a citar um trecho da estudiosa Maria da Paz Ribeiro Dantas, autora de texto que analisa "Visão do último trem subindo ao céu", segundo poema deste livro. ${ }^{14}$ Da mesma forma, Stegagno-Picchio privilegia o olhar sobre este poema, tendo citado dois versos do mesmo em seu breve estudo.

A análise da presença e frequência dos poemas nos volumes aqui estudados, também permite levantar algumas conjecturas sobre a importância do livro na ressonância de Joaquim Cardozo neste tipo de discurso. Nenhuma das obras historiográficas estudadas menciona as atividades literárias de Cardozo antes da publicação de Poemas em 1947, publicação essa tardia, uma vez que o autor já contava 50 anos, e escrevia e publicava em periódicos há mais de três décadas na ocasião. Dessa forma, percebe-se um forte movimento das histórias de literatura de se modularem especialmente em textos publicados em livros, sendo este o meio que consolidaria de maneira mais ampla a inserção do autor no âmbito de tais estudos.

Outrossim, o estudo aponta para uma hipótese importante, que indicaria como uma das principais fontes de pesquisa dos historiadores da literatura brasileira justamente os próprios estudos historiográficos. Em linhas gerais, percebe-se que o primeiro momento editorial que levou o autor a um reconhecimento no âmbito nacional foi a inclusão de seu nome na Antologia de poetas contemporâneos bissextos de Manuel Bandeira, na década de 1946, citada explicitamente por Coutinho e Stegagno-Picchio, autora que em seu capítulo I, intitulado "Bibliografia geral", esclarece ter consultado todas as antologias do poeta de Pasárgada. Além disso, a estudiosa italiana também informa como fonte a Pequena antologia poética pernambucana, que João Cabral de Melo Neto publicou sob o selo de sua editora "O livro inconsútil", considerada um dos molares que impulsionou a lírica cardoziana para uma

14 O autor cita a obra de Dantas intitulado O mito e a ciência na poesia de Joaquim Cardozo, publicado em 1985 pela editora José Olympio em convênio com a FUNDARPE/Recife. Nejar também menciona no capítulo o livro da autora intitulado Joaquim Cardozo, contemporâneo do futuro, de 2004, referendando-o como "um livro primoroso com a análise de sua obra e seleção de poemas". (NEJAR, 2007, p. 232). 
maior visibilidade. Stegagno-Picchio também cita como referências à pesquisa da poesia pernambucana as antologias de Edilberto Coutinho, Presença poética do Recife (1977) e de Oliveira e Silva, Coletânea de poetas pernambucanos (1951). Fora das antologias, a autora aponta como uma de suas fontes o livro de Souza Barros (1972) que hoje é uma referência obrigatória nos estudos sobre o cenário cultural de Recife no início do século, A década de 20 em Pernambuco.

Por seu lado, Nejar menciona a antologia organizada por César Leal ${ }^{15}$, além de enumerar, ao final de seu texto, algumas fontes historiográficas que lhe serviram de suporte: a História concisa da literatura brasileira, de Alfredo Bosi (1970), a Enciclopédia da literatura brasileira, de Afrânio Coutinho e J. Galante de Souza (2001), a História da literatura brasileira, de Luciana Stegagno-Picchio (1997) e a Correspondência de Cabral com Bandeira e Drummond, de Flora Süssekind (2001), que em alguns trechos sinalizam para a relação entre Cabral e Cardozo e também Bandeira e Cardozo.

$\mathrm{Na}$ análise aqui proposta, também foi possível notar o quanto houve um progressivo intercâmbio entre este gênero e a crítica literária, especialmente nas histórias da literatura brasileira mais recentes. Na bibliografia ao final do volume (p. 552), Moisés apresenta como fontes consultadas algumas leituras críticas, como A luta literária, de Fausto Cunha (1964), Seis poetas e um problema, de Antônio Houaiss (1960), Participação da palavra poética, de Sebastião Uchoa Leite (1966), Literatura e civilização, de Franklin de Oliveira (1978), Chão de crítica, de Fernando Py (1984) e, como já apontado acima, Razão do poema, de José Guilherme Merquior (1965), livro igualmente citado na bibliografia ao final do volume de Nejar. A essa obra, o historiador mais recente junta Modernismo e regionalismo, de Neroaldo Pontes de Azevedo (1996), o qual apresenta uma extensa análise do cenário cultural na década de 20 em Recife. Stegagno-Picchio, por sua vez, também menciona a consulta a algumas revistas de estudos literários que publicaram textos de e sobre Joaquim Cardozo, como Para todos e Poesia sempre.

No entanto, é perceptível que a referência crítica mais impactante no corpus estudado é o primeiro estudo sobre os poemas de Cardozo publicado em um âmbito nacional e já várias vezes aqui citado, o prefácio de Carlos Drummond de Andrade em Poemas. Coutinho inicia seu item sobre Joaquim Cardozo mencionando este texto, ao indicar a problemática da categorização do autor como modernista, que será discutida nos demais historiadores, ou seja, o posicionamento independente do autor frente ao período literário no qual ele se insere.

15 Poemas selecionados, antologia organizada por César Leal que foi publicada pelas Edições Bagaço em Recife em 2008. 
Stegagno-Picchio não cita literalmente a publicação de Poemas, no entanto referencia, sem lhe atribuir a autoria, uma frase, "modernista mais ausente do que participante" (DRUMMOND apud CARDOZO, 1947, p. 8), e um verso de "Imagens do Nordeste" que, não coincidentemente, também fora transcrito no texto de Drummond. Ademais, outras questões levantadas do poeta de Itabira também foram apontadas pelos autores aqui analisados, como o estilo racional e construtivo de seus versos, que se equipariam ao fazer poético de Valéry, a força da intelectualidade que modularia um projeto poético bem mais amplo que as referências regionais, as tensões e complexidades de uma lírica que se fazia experimental e inquieta. Assim, pode-se dizer que o olhar arguto de Drummond, que vislumbrou já no primeiro livro de Cardozo as potencialidades de sua poesia, foi, com certeza, um condutor significativo de várias estudos sobre a obra do poeta e engenheiro pernambucano.

Por fim, em relação aos movimentos de atualização das informações dos autores nas obras historiográficas aqui vistas, e, considerando que, afora A literatura no Brasil de Coutinho, as demais vieram a lume após a morte do autor em 1978, nota-se que as menções a sua bibliografia ativa, ainda se encontram incompletas e imprecisas. Isto pode ser um indicador importante da ainda escassa inserção da lírica de Joaquim Cardozo nos leitores de poesia deste período, mesmo entre os especialistas.

De maneira geral, o levantamento realizado aqui demonstra certamente que os estudos historiográficos sobre Cardozo se ampliaram com o tempo, quantitativa e qualitativamente, especialmente na medida em que o cânone se abriu para a descentralização das regiões e de pressupostos rígidos de vinculação estética. Por um motivo ou outro, por vieses diversos, a complexa e incontestável lírica de Joaquim Cardozo tem se fixado como parte significativa de um extenso período literário nacional, no entanto, certamente é merecedora de abordagens mais amplas.

\section{Referências Bibliográficas}

ANDRADE, Carlos Drummond de. [Prefácio]. CARDOZO, Joaquim. Poemas. Rio de Janeiro: Agir, 1947. p. 7-13.

CARDOZO, Joaquim. Poemas. Rio de Janeiro: Agir, 1947.

Gláuks: Revista de Letras e Artes - jul./ dez. 2019 - Vol 19, $N^{o} 2$, ISSN 2318-7131 
. Poesia completa e prosa. Organização e introdução geral de Everardo Norões. Rio de Janeiro: Nova Fronteira; Recife: Fundação Joaquim Nabuco, Massangana, 2010.

D'ANDREA, Moema. A cidade poética de Joaquim Cardozo. Elegia de uma modernidade. João Pessoa-PB: The document company, 1998.

HOUAISS, Antônio. Drummond mais seis poetas e um problema. Rio de Janeiro: Imago, 1976.

MOISÉS, Massaud. História da literatura brasileira. Modernismo. São Paulo: Cultrix, 1995.

NEJAR, Carlos. História da literatura brasileira. Da carta de Pero Vaz de Caminha à contemporaneidade. Rio de Janeiro: Relume Dumará; Copesul; Telos, 2007.

RAMOS, Péricles Eugênio da Silva. Joaquim Cardozo. In: COUTINHO, Afrânio (direção); COUTINHO, Eduardo de Faria (co-direção). A literatura no Brasil. $3^{\mathrm{a}}$. edição, revista e atualizada. José Olympio; Editora da Universidade Federal Fluminense, 1986. P. 154-156.

STEGAGNO-PICCHIO, Luciana. História da literatura brasileira. Rio de Janeiro: Nova Aguilar, 1997.

\title{
The lyrical poetry of Joaquim Cardozo in brazilian literature history: some notes
}

\begin{abstract}
This study study aims to analyze how the Histories of Brazilia literatura registered the lyrics of Joaquim Cardozo, in order to elucidate the processes by which this occured and how such procedures contributed to consolidate the relevance of this poetry in this contexto. For this, his figuration was analyzed in the following books: A literatura no Brasil, by Afrânio Coutinho (1958); História da literatura brasileira, by Massaud Moisés (1989); História da literatura brasileira, by Luciana Stegagno-Picchio (1997); and História da literatura brasileira, by Carlos Nejar (2007). The investigation presents a discussion of the main sources that were used in the confrontation of the subject by these stories, which poems were reiterated, and which analytical perspectives were stated.
\end{abstract}

Keywords: Modern brazilian poetry, Brazilian literature History, Joaquim Cardozo. 